\title{
Florida Predatory Stink Bug (unofficial common name), Euthyrhynchus floridanus (Linnaeus) (Insecta: Hemiptera: Pentatomidae) ${ }^{1}$
}

Frank W. Meed and David B. Richman²

\section{Introduction}

The predatory stink bug, Euthyrhynchus floridanus (Linnaeus), is considered a beneficial insect because most of its prey consists of plant-damaging bugs, beetles, and caterpillars. This stink bug is primarily a Neotropical species that ranges into southeastern quarter of the United States. It seldom plays more than a minor role in the natural control of insects in Florida, but its prey includes such economic species as southern green stink bug, Nezara viridula (Linnaeus); orangedog, Papilio cresphontes Cramer; velvetbean caterpillar, Anticarsia gemmatalis Hübner; Colorado potato beetle, Leptinotarsa decemlineata (Say); West Indian sugarcane rootstalk borer, Diaprepes abbreviatus (Linnaeus), and others.

\section{Identification}

Eggs: The females lay egg masses with individual eggs somewhat barrel shaped. Eggs and all five nymphal instars were illustrated and described in detail by Oetting and Yonke (1975). Eggs of E.

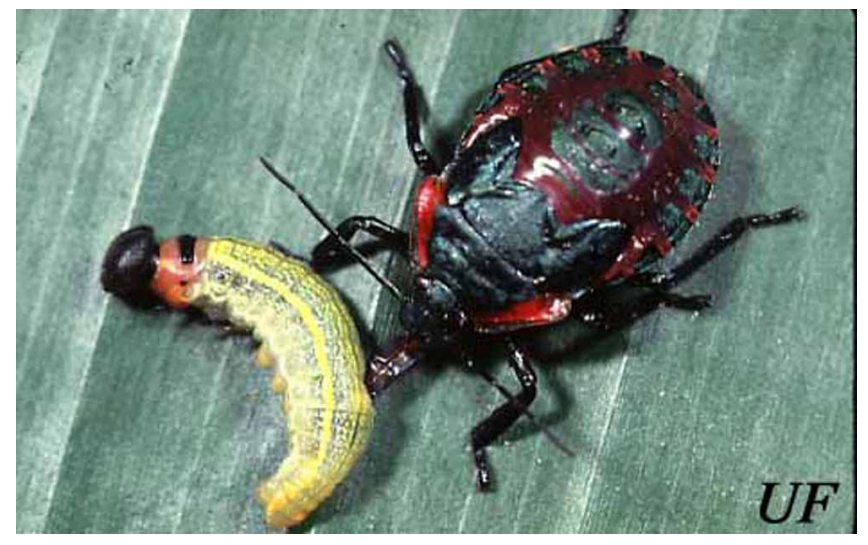

Figure 1. A nymph of the predatory stink bug Euthyrhynchus floridanus (L.) attacking a bean leafroller. Credits: University of Florida

floridanus are approximately $1 \mathrm{~mm}$ in diameter, with short projects around the operculum, and are laid 20 to 90 at a time.

Nymphs: Identification of the nymphs is less certain, particularly the earlier instars. The available keys are based on the last instar (5th), but key characters often apply to the 4th instar as well. Hart (1919) included a key to nymphs in the various stink

1. This document is EENY-157 (originally published as DPI Entomology Circulars 174 and 242), one of a series of Featured Creatures from the Entomology and Nematology Department, Florida Cooperative Extension Service, Institute of Food and Agricultural Sciences, University of Florida. Published: September 2000. This document is also available on Featured Creatures Website at http://creatures.ifas.ufl.edu. Please visit the EDIS Website at http://edis.ifas.ufl.edu. Additional information on these organisms, including many color photographs, is available at the Entomology and Nematology Department website at http://entnemdept.ifas.ufl.edu/.

2. Frank W. Meed, Florida Department of Agriculture and Consumer Services, Division of Plant Industry, and David B. Richman, University of Florida.

The Institute of Food and Agricultural Sciences is an equal opportunity/affirmative action employer authorized to provide research, educational information and other services only to individuals and institutions that function without regard to race, color, sex, age, handicap, or national origin. For information on obtaining other extension publications, contact your county Cooperative Extension Service office. Florida Cooperative Extension Service/Institute of Food and Agricultural Sciences/University of Florida/Christine Taylor Waddill, Dean. 


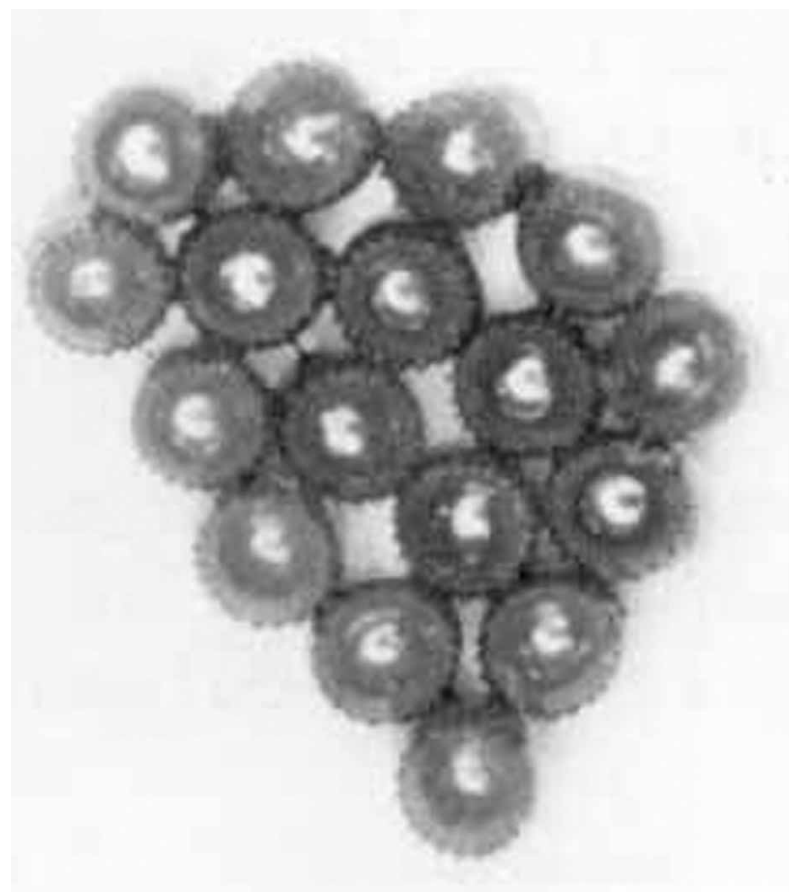

Figure 2. Eggs of Euthyrhynchus floridanus (Linnaeus), a predatory stink bug. Credits: Division of Plant Industry

bug subfamilies. DeCoursey and Allen (1968) published a key to the 5th instar nymphs of 25 genera of eastern U.S. stink bugs. However, four asopine genera (Alcaeorrhynchus, Andrallus, Mineus, Oplomus) reported from Florida were not included. Also listed were field recognition characters of mature nymphs, with Euthyrhynchus summarized as having head, thorax, lateral and medial plates unicolorous metallic green, abdomen bright red; length $8-9 \mathrm{~mm}$. The mature nymphs reared by Oetting and Yonke were 10 to $12.5 \mathrm{~mm}$ in length. An occasional mistake of a few beginners is to confuse Euthyrhynchus nymphs with beetles. The latter would have elytra forming a suture dorsally, and the mouthparts would be of the chewing type. Also, the young stink bugs lack wings and have tubelike piercing-sucking mouthparts.

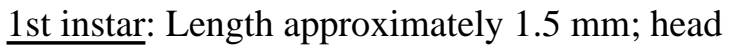
width, including eyes, $0.7 \mathrm{~mm}$; humeral width 1.0 $\mathrm{mm}$. These are difficult to distinguish from the 1st instar nymphs of Alcaeorrhynchus grandis (Dallas): both have a blue-black head and thorax and red abdomen with dark central and lateral "stripes" composed of dorsal and lateral dark colored plates. Nymphs of this age do not stray far from the egg mass and may be distinguished by association with

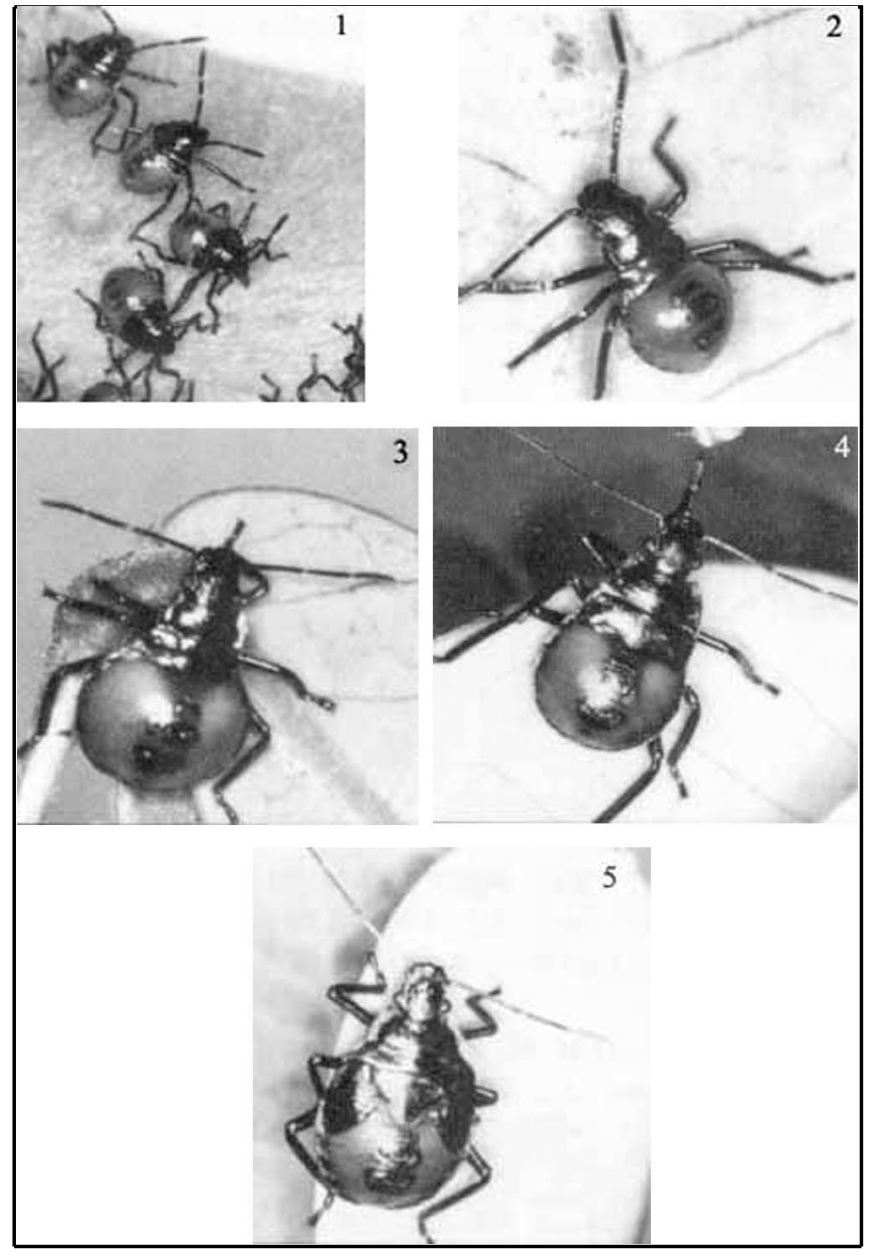

Figure 3. Nymphs of the predatory stink bug Euthyrhynchus floridanus (L.): 1) 1st instar nymphs, 2) 2nd instar nymph, 3) 3rd instar nymph, 4) 4th instar nymph, 5) 5th instar nymph. Credits: Division of Plant Industry

the form of the mass and the numbers of eggs; $A$. grandis masses are in multiple rows and contain 100 to 200 eggs.

2nd instar: Length 2 to $2.5 \mathrm{~mm}$; head width 0.9 $\mathrm{mm}$; humeral width $1.1 \mathrm{~mm}$. As in other asopine stink bugs, E. floridanus begins to capture insect prey as a 2nd instar nymph. It looks much like the 1 st instar and retains the same coloration.

3rd instar: Length approximately $4 \mathrm{~mm}$; head width $1.2 \mathrm{~mm}$; humeral width $1.7 \mathrm{~mm}$; colored much as in the 1st instar. The iridescence of the blue-black markings is more noticeable because of the larger size of the nymph.

4th instar: Length 6 to $7 \mathrm{~mm}$; head width $1.7 \mathrm{~mm}$; humeral width $2.9 \mathrm{~mm}$; much like the earlier stages in appearance. 
5th instar: Length 8 to $9 \mathrm{~mm}$; head width $2.1 \mathrm{~mm}$; humeral width $4.8 \mathrm{~mm}$. The wing pads, which are blue-black, are prominent, but otherwise the nymph is much like the preceding stages.

Adults: Male length approximately $12 \mathrm{~mm}$; head width $2.3 \mathrm{~mm}$; humeral width $6.4 \mathrm{~mm}$. Female length $12-17 \mathrm{~mm}$; head width $2.4 \mathrm{~mm}$; humeral width 7.2 $\mathrm{mm}$. E. floridanus normally can be distinguished from all other stink bugs in the southeastern U.S. by a reddish spot at each corner of the scutellum outlined against a blue-black to purplish brown ground color. Variations occur that might cause confusion with somewhat similar stink bugs in several genera such as Stiretrus, Oplomus, and Perillus, but these other bugs have obtuse humeri or at least lack the distinct humeral spine that is present in adults of Euthyrhynchus. In addition, species of these genera known to occur in Florida have a short spine or tubercle situated on the lower surface of the front femur behind the apex $1 / 4$ to $1 / 3$ of the femoral length. Hayslip et al. (1953) illustrated species in Stiretrus, Euthyrhynchus, and Podisus, and a prominently marked E. floridanus was illustrated by Chittenden (1911).

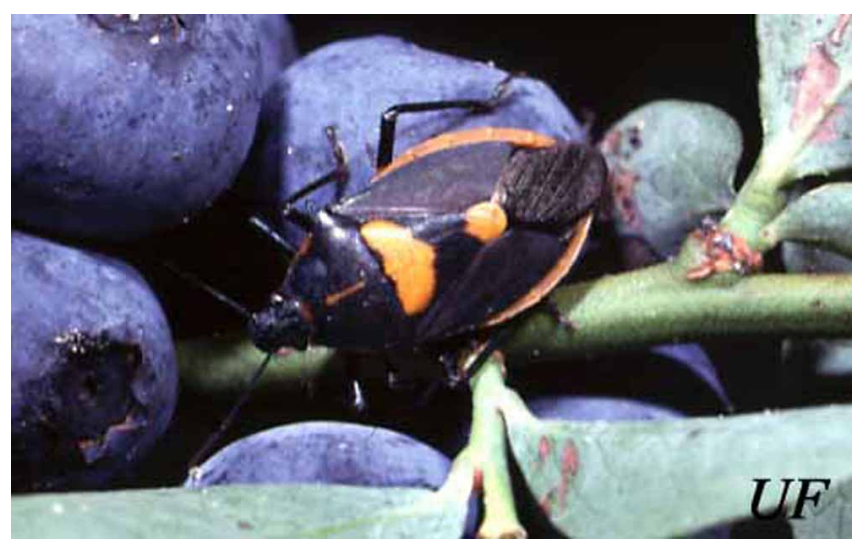

Figure 4. Adult predatory stink bug Euthyrhynchus floridanus (L.). Credits: University of Florida

The adults of E. floridanus are often confused with the banded form of Stiretrus anchorago (Fabricius), from which it differs in size ( $S$. anchorago is less than $10 \mathrm{~mm}$ long), shape (S. anchorago is more globose and resembles a leaf beetle), and scutellum size (S. anchoragoe has a very large scutellum covering much of the dorsum of the abdomen).
The basic characters of the predatory subfamily Asopinae serve to eliminate the much more common plant feeding stink bugs: asopines have the first segment of the beak short and thick, free, only its base being between the bucculae which converge and unite behind or beneath the beak. The base of beak is close to the end of the tylus. Other groups of stink bugs have the first segment of beak slender, and embedded between the bucculae which are wide and parallel. The base of the beak is distinctly separated from the end of the tylus. Blatchley (1926) and Torre- Bueno (1939) remain the basic keys to stink bugs in the eastern U.S.

\section{Life History}

E. floridanus has been reared in the laboratory by Ables (1975), Oetting and Yonke (1975), and Richman and Whitcomb (1978). At 26 to $27 \mathrm{C}$ and with a photoperiod of 14:10 both Ables and Richman and Whitcomb found that the length of time from egg to adult was 58 days. The egg stage lasted 18 to 19 days.

Ables (1975) reared South Carolina examples of E. floridanus in the laboratory, providing prey of greater wax moth larvae, Galleria mellonella (L.), all stages of Mexican bean beetle, Epilachna varivestis Mulsant, and larvae of tobacco budworm, Heliothis virescens $(\mathrm{F}$.). The life cycle was about 89 days under the conditions provided. Oetting and Yonke (1975) reared Missouri stock of $E$. floridanus in the laboratory, providing black cutworms, Agrotis ipsilon (Hufnagel) as a food source. Oetting and Yonke (using a temperature of $24 \mathrm{C}$ and a photoperiod of 13:11) found the length of time from egg to adult was 100 days, with the egg stage lasting 33 days.

These papers (Ables 1975, Oetting and Yonke 1975) included comments on the gregarious nature of the nymphs and even the adults tended to aggregate at night in the cages. Ables (1975) commented that capture of prey and feeding by early instars often appeared to be a group effort. He added that such behavior would be of a selective advantage because it would allow feeding on large prey unavailable to a single nymph.

Records in the Florida State Collection of Arthropods show that E. floridanus has been collected 


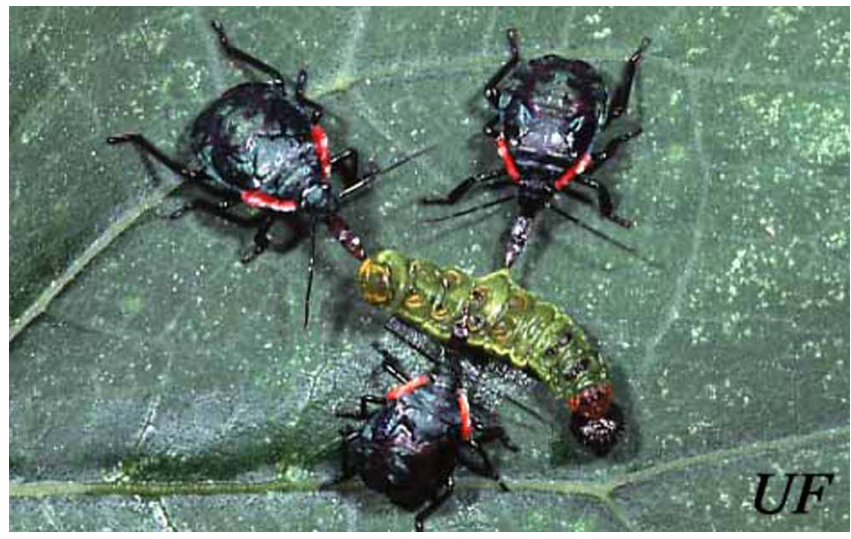

Figure 5. Nymphs of the predatory stink bug Euthyrhynchus floridanus (L.) exhibiting group predatory behavior by jointing attacking a bean leafroller. Credits: University of Florida

during all months of the year in Florida. There is a peak in the spring and again in the fall. Of 140 habitat records, $25 \%$ have been ornamentals, $17 \%$ citrus; $8 \%$ in traps, $6 \%$ in weeds and turf, and the remainder in miscellaneous fruits, trees, and random habitats. Prey records include Nezara viridula (L.), Diaprepes abbreviatus (L.), a leaf beetle, Bassareus brunnipes (Oliv.), and a flatid planthopper, Ormenaria (=Monoflata) rufifascia (Walker). Prey reported in the literature includes velvetbean caterpillar, Anticarsia gemmatalis Huebner, Colorado potato beetle, Leptinotarsa decemlineata (Say), walnut caterpillar, Datana integerrima Grote \& Robinson, alfalfa weevil, Hypera postica (Gyllenhal), a ctenuchid, Lymire edwardsii (Grote), "okra" or "mallow" caterpillar, Cosmophilla erosa Huebner.

\section{Survey and Detection}

\section{E. floridanus has been collected during all} months of the year in Florida.

2. It can be collected in a wide variety of habitats because the prey is highly variable.

3. Specimens can be collected by hand or net, and submitted for identification in alcohol-filled vials or dry in pill boxes.

4. Make special effort to submit egg mass associated with young nymphs.

\section{Selected References}

- Ables JR. 1975. Notes on the biology of the predacious pentatomid Euthyrhynchus floridanus (L.). Journal of the Georgia Entomological Society 10: 353-356.

- Blatchley WS. 1926. Heteroptera or true bugs of North America with special reference to the faunas of Indiana and Florida. Nature Publ. Co., Indianapolis. $1116 \mathrm{p}$.

- Chittenden FH. 1911. Notes on various truck-crop insects. United States Dept. Agr., Bur. Ent. Bull. 82, Part VII, 85-93.

- DeCoursey RM, Allen RC. 1968. A generic key to the nymphs of the Pentatomidae of the eastern United States (Hemiptera: Heteroptera). Univ. Connecticut Occas. Papers 1: 141-151.

- Distant WL. 1880-1893. Insecta. Rhynchota. Hempitera: Heteroptera. Vol. 1. In Biologia Centrali-Americana: London xx +462 p.

- Hart CA. 1919. The Pentatomoidea of Illinois with keys to the Nearctic genera. Bull. Illinois Nat. Hist. Survey 13: 157-223.

- Hayslip NC, Genung WG, Kelsheimer EG, Wilson JW. 1953. Insects attacking cabbage and other crucifers in Florida. Florida Agr. Exp. Sta. Bull. 534: 1-57.

- Hoffman RL. 1971. The insects of Virginia: No. 4. Shield bugs (Hemiptera: Scutelleroidea: Scutelleridae, Corimelaenidae, Cydnidae, Pentatomidae). Virginia Polytechnic Inst. and State Univ., Res. Div. Bull. 67: 1-61.

- McDonald FJD. 1966. The genitalia of North American Pentatomoidea (Hemiptera: Heteroptera). Quaestiones Entomologicae 2: 7-150.

- Oetting RD, Yonke TR. 1975. Immature stages and notes on the biology of Euthyrhynchus floridanus (L.) (Hemiptera: Pentatomidae). Annals of the Entomological Society of America 68: 659-662. 
- Richman DB, Whitcomb WH. 1978.

Comparative life cycles of four species of predatory stink bugs (Hemiptera: Pentatomidae).

Florida Entomologist. 61: 113-119.

- Torre-Bueno JR. de la. 1939. A synopsis of the Hemiptera: Heteroptera of America north of Mexico. Part 1. Families Scutelleridae, Cydnidae, Pentatomidae, Aradidae, Dysodiidae and Temitaphididae. Ent. Americana 19:

141-304. 